\title{
USE OF GADGETS IN BIOLOGY CLASSES AS A MEANS OF INCREASING STUDENTS' MOTIVATION
}

\author{
VICTORIA GNIEZDILOVA
}

\begin{abstract}
The article highlights the current problem of motivating students to learn. The use of gadgets in the educational process can positively affect the motivation of students to learn, involve them in creative activities, as well as interest in better and more honest performance of tasks. Since most students are bored at school, it is difficult to involve them in active work in the classroom. The problem of increasing student activity in the classroom is a fairly common and urgent today. It is difficult to imagine a world without modern technology. Laptops, mobile phones, tablets, computers and other gadgets have become good friends for people. They are real colleagues: they help perform many tasks, which normally take a long time to solve. As with any adult, gadgets play a significant role in children's lives. Teenagers and mobile phones are the same inseparable things as teachers and well-prepared notes. Children are increasingly choosing entertainment in front of a monitor, instead of playing outside or walking with family. Social networks, wellthought-out computer games, take the first place among youth hobbies. That is why the important task facing teachers is to arouse interest in learning, to motivate students. And here ICT are simply irreplaceable: they are the chain that connects the interests of teachers and students. You just need to learn to creatively use children's hobbies with gadgets. Our research has shown how students' attitudes towards biology lessons and their motivation to learn have changed after using the online lab on the Go-Lab platform, the Kahoot application, and QR-codes.
\end{abstract}

Keywords: motivation, gadgets and electronic devices, learning process, school students, biology lessons.

\section{INTRODUCTION}

Today, the problem of motivating students to learn is quite relevant. Most teachers encounter it during school days, because the primary task of the teacher is to support children's interest in mastering the school program, to create favorable conditions for learning new information, as well as to develop a desire to learn something new, unknown.

In these conditions, an important component of the learning process is the motivation of the student. It depends on their thirst for knowledge, their interest, depth of knowledge, desire and ability to learn for more than one school year. According to the research, only $20 \%$ of successful work depends on a person's abilities and $80 \%$ on his motivation.

Today's realities encourage teachers to be creative in the learning process, to look for such forms of classes that would captivate students, promote better learning, development of abilities and the desire to improve their knowledge and skills. Jan Amos Comenius argued that interest was the driving force of learning, and the original form of knowledge helped avoid monotony, stereotypes, promotes the 
wider use of effective methods and techniques of learning new knowledge by students [8]. Thus, the first task facing the teacher is to arouse interest in learning, to motivate students. So, ICT are simply irreplaceable: they are the chain that connects the interests of teachers and students. You just need to learn to creatively use children's fascination with gadgets.

The integration of digital technologies into the educational process helps increase the efficiency of education. E-learning is the creation of a certain environment that differs from the traditional classroom learning and is aimed at obtaining new educational results. E-learning significantly expands the range of technical means used. The basic idea of this approach is that we should make technical means an integral part of the educational process.

\section{ANAlysis of Research AND Publications}

The problem of using gadgets in the educational process is covered in the works of many scientists, methodologists and teachers-practitioners: O. Budnyk, T. Blyznyuk, N. Morze, N.Grytsai, V. Shuldyk, N. Sheludiakova, O. Bagrova, L. Nesterova, A. Baranova, K. Savchenko and others. However, they contain only general theoretical principles of using information and communication technologies, web technologies, cloud and remote technologies, educational electronic resources, etc. in the educational process $[2,3,9,10]$. Teachers lack practical guidance on the use of digital technologies in the teaching of certain school subjects. In addition to the great interest of researchers in the problem of digitalization of education, many government regulations contain numerous requirements for the introduction of digital technologies in the educational process: "On conducting a pedagogical experiment on teaching future teachers and teachers of information and communication technologies", "Concept of scientific, technical and innovative policy in the system of higher education of Ukraine", "On the functioning of the Internet portal "Unified educational information window of Ukraine", "On measures to implement e-learning content", "Regulations on electronic educational resources", "On creating an informationeducational environment based on open electronic resources "Shchodennyk.ua", "On the systematization of the experience of using electronic educational resources", etc.

\section{PuRpose AND Objectives of THE RESEARCH}

The purpose of our study was to find out how to use the online lab on the Go-Lab platform, the mobile application Kahoot! and QR-codes in biology lessons affect students' motivation to learn.

\section{RESUlTS AND DISCUSSION}

Motivation to learn is considered one of the main conditions for the formation of the educational process. It not only promotes the development of intelligence, but is also the main driving force that guides the student. The formation of educational motivation of students is one of the main problems of today.

According to A. Markova, the formation of learning motivation means transferring the student to such conditions, the appropriate problem situation, where motives and goals would develop, taking into account previous experience, individuality and internal needs of the student [8].

Motivation in the learning process is one of the main factors of effective education. Motivation during the learning process affects the desire of students to actively learn. There are many theories of the formation of motivational activities of students. The main thing for a teacher is that students feel an inner need to learn. Therefore, the teacher must create appropriate conditions, a certain learning environment. However, to create these conditions, first of all it is necessary to understand what and how influences the formation of motivation, to get acquainted with its types, to identify which methods should be used to increase the motivational activity of students during the learning process.

So, the motive is the cause of action, and motivation is the inner state of man. It is invisible and only accompanies the process of achieving the goal, speeding up or slowing them down. The key to 
understanding motivation is the meaning and relationship between needs, drivers and goals. The main processes of motivation lead to the achievement of goals [4].

When a student has a problem, he/she cannot explain certain concepts or answer questions, he will most likely seek help from a teacher, open a textbook or use the Internet to get the knowledge he needs.

In the works, the psychologist and educator Gottfried defined academic motivation as "the pleasure of schooling, which is characterized by skill, interest, persistence in solving complex and new problems" [7].

From the very beginning of studying different subjects at school, students immediately focus on some of them. Namely, those whom they believe they have the necessary competence or focus on those subjects that they value more than others and believe that the study of these disciplines may be needed in the future, for example, to obtain the desired profession.

Recent research suggests that two important learning strategies should be implemented. The first strategy concerns the ability of students to initiate a decision plan without much hesitation. The second strategy concerns children's ability to assess whether it is useful to continue their action plan to solve the problem, to show persistence, or whether it is better to give up, because it will not lead anywhere [4].

However, we should not forget about the goals that children set for themselves when coming to school. Teachers, educators and parents believe that the acquisition of new knowledge and skills is the most important goal that students should strive for in the school context. The reality is different.

Young people do not consider the learning goals set by the teacher to be the most visible goals in their lives. They pursue many other goals.

For example, they want to be treated fairly, want to make a network of friends, learn more about their favorite topics about a subject, build relationships with peers, socialize, occupy a certain place in the school hierarchy, and engage in discussions with their romantic partners, each other, their parents. After all, the school is a place filled with children who want to live a full life, not focusing only on learning new material. These personal goals play a crucial role in motivational processes, determining their content, direction and intensity.

Recent evidence suggests that students are more motivated to do their homework when schoolrelated goals are aligned with their own wishes, needs, and expectations [7].

Students who note that the teacher acknowledges their personal desires are more receptive to the teacher. Conversely, children who realize that their personal desires are being ignored rebel against the system and consider the curriculum alien to their "real" life.

For decades, teachers and researchers have narrowed their educational goals to learning, destroying students' social desires.

Students bring their own goal to the class and want to agree with the teacher on how, when and with whom they want to achieve such a goal, and how learning can help them.

It is important to realize that teachers put their students in different situations in which they must develop their social skills and ideas. For example, teachers simulate situations where students have to work individually, without the support or help of peers, or vice versa, children have to work in small groups and are responsible for teaching all group members.

In the age of digital technology, various gadgets are used in all sides of life. The educational process is no exception. But its participants are divided into two camps, where some believe that the use of modern devices has a positive effect on learning, while others are convinced that they are harmful to the educational process [6].

Teachers believe that the use of modern gadgets in the educational process has its positive aspects, but their absence is not critical. With the help of devices you can get free access to any information in one minute, communicate with all participants in the educational process. The realities of the modern world contribute to the creation of opportunities for online learning, which allows you to learn anywhere and anytime, using educational content on electronic platforms.

The use of various gadgets in the form of interactive whiteboards, educational mobile applications, electronic textbooks, diaries, etc. during the organization of the educational process in schools 
promotes a creative approach that makes learning interesting, dynamic, exciting, modern and effective [10]. This motivates students to study. During the lesson, students "help" the teacher conduct the lesson: they look for information using their own smartphones. Or in general, the lesson involves an independent student search for information on the Internet on a topic that they have not yet analyzed. Then the lesson turns into a seminar on the analysis of knowledge gathered by students. Such techniques help the teacher change children's attitudes to the latest technologies. If students use gadgets in the real learning process, they stop treating the smartphone as entertainment. Thus, the concept of E-learning forms the habit of using the gadget as a source of knowledge and skills.

We conducted research on the controlled use of gadgets to motivate students to learn, using mobile phones, laptops, online labs on the Golabz platform, the application Kahoot, QR-codes.

First, we updated the basic knowledge of students, replacing the usual oral examination with testing using the mobile application Kahoot. In the lesson of learning new knowledge, students received illustrations on the topic on their smartphones by scanning the QR-code. This allowed to analyze the acquired knowledge and immediately apply it in practice, visually consolidating the material. At the same time, all the new information was stored in a separate file in the mobile phone, which allowed to use it when doing homework.

Before the study, $40.0 \%$ of students rated biology lessons at four, $30.0 \%$ at three, $17.0 \%$ of students rated lessons at two, and $13.0 \%$ of learners rated biology lessons at one of five possible points. Regarding the use of gadgets in lessons, $66.0 \%$ of students said that they do not use modern technology in the educational process and only $34.0 \%$ replace textbooks with electronic tablets, based on the practicality of using the gadget, because it is much more convenient to carry a tablet to school. fit all textbooks than a heavy backpack with books.

After conducting lessons using the online lab on the Golabz platform and other mobile applications, we saw what changes the use of modern technology has made and how it has affected students' perception of new material and their motivational activities.

The study showed that $23.0 \%$ of students rated such biology lessons on a solid four, and $77.0 \%$ on five points out of five possible. No three, two or one lessons were received.

The students confirmed that they would like to use mobile phones more often in biology lessons. Most of them praised the online testing with the Kahoot! app. The children also said that they were much more interested in perceiving the new information, having at hand illustrations to the topic, which they received on a mobile device, reading the QR-code.

To assess students' activity and motivation in biology lessons, we made some observations, keeping track of how many students respond to the lesson, how many take an active part in discussing a new topic, and taking into account those who work at the intermediate level. That is, part of the lesson the student works, part does not. We also took into account the number of students who behave passively in class. They take little notes, often distract from the teacher's story, try to talk to their classmates, or ask questions that are not related to the lesson topic.

As a result of our observations, we obtained the following results: on average, 10 students out of thirty were passive, 14 students showed average activity and interest in the lesson, while only 6 students in the class were well motivated and active in the lesson (Fig. 1). 


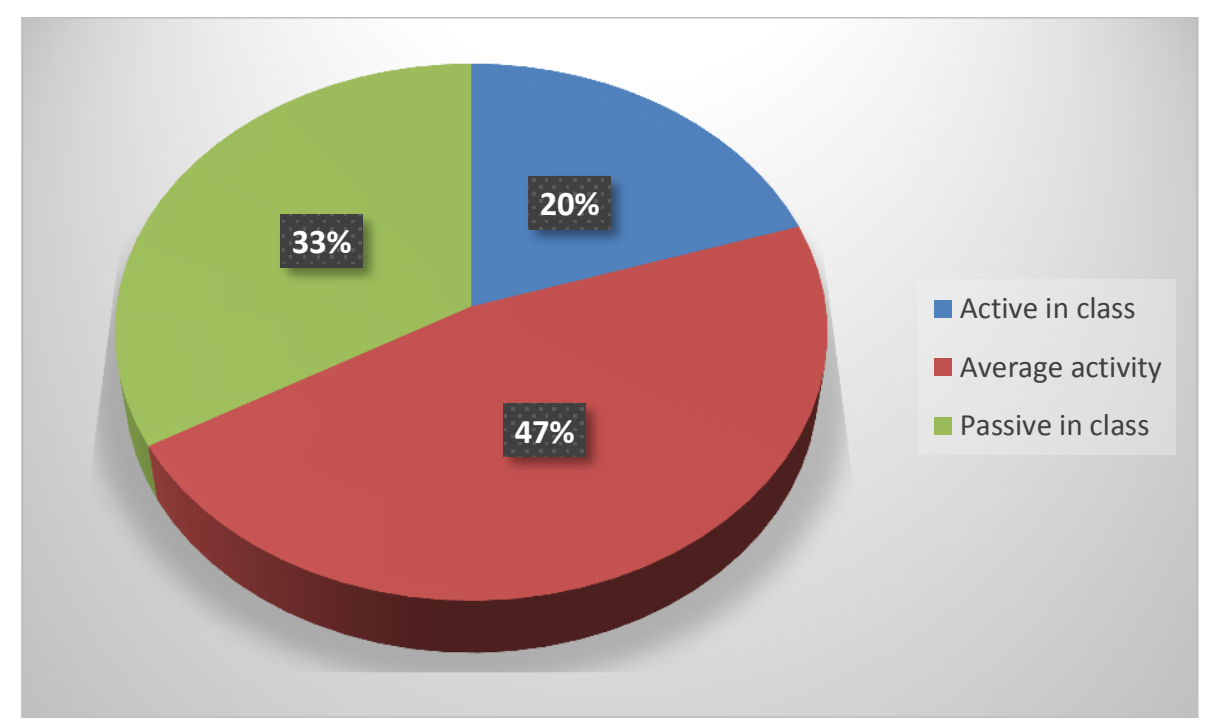

Fig.1. Activity and motivational activity of students before the use of innovative technologies in biology lessons.

The situation changed during classes using gadgets. Interest in lessons and motivation of children has significantly improved.

During the study, 11 out of 30 students worked actively in class, the average activity and motivation in the class also increased 17 children worked at this rate.

Such results can be explained by the fact that children are interested in the introduction of the technical component in learning. During the rapid development of technology, the old teaching methods are no longer of interest to children, so such a radical change in the usual mode of study for students brought a positive effect and, of course, attracted a lot of attention. Students were able to feel in a new environment that allowed them to "keep up" with modernity, use mobile phones in lessons with the permission of the teacher, work in a virtual laboratory, it raised interest in studying biology.

However, two students still remained uninterested in learning. Even the introduction of modern technologies into the educational process failed to raise their motivation and interest (Fig. 2).

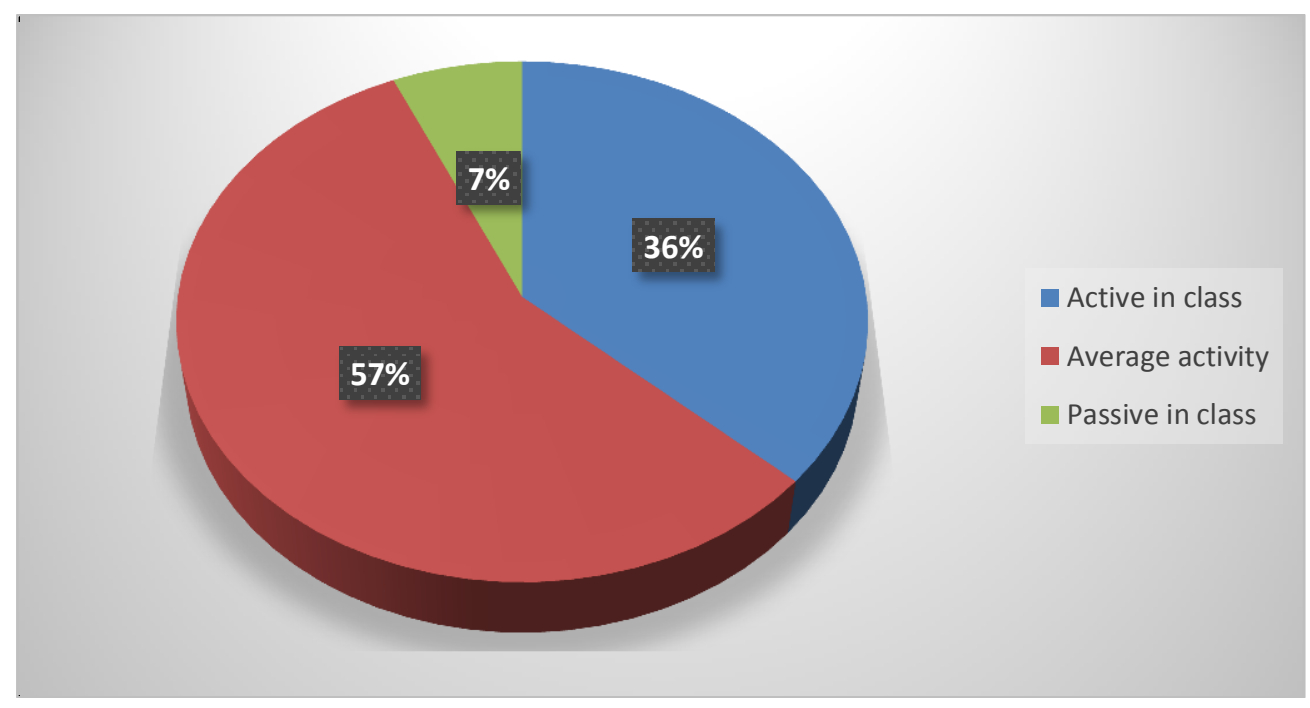

Fig. 2. Activity and motivational activity of students after the use of innovative technologies in biology lessons.

Thus, the number of well-motivated and active students in biology lessons at the beginning of the study was $20.0 \%$, and at the end $-37.0 \%$. The average activity of knowledge seekers in the classroom also changed, at the beginning of the study it was $47.0 \%$, at the end $-57.0 \%$. The rate of inactive students has changed the most. At first it was $33.0 \%$, and in the end only $6.0 \%$. That is, the activity of 
students increased by $17.0 \%$, the average activity increased by $10.0 \%$, and the passive work of children in biology lessons decreased by $27.0 \%$ (Fig. 3).

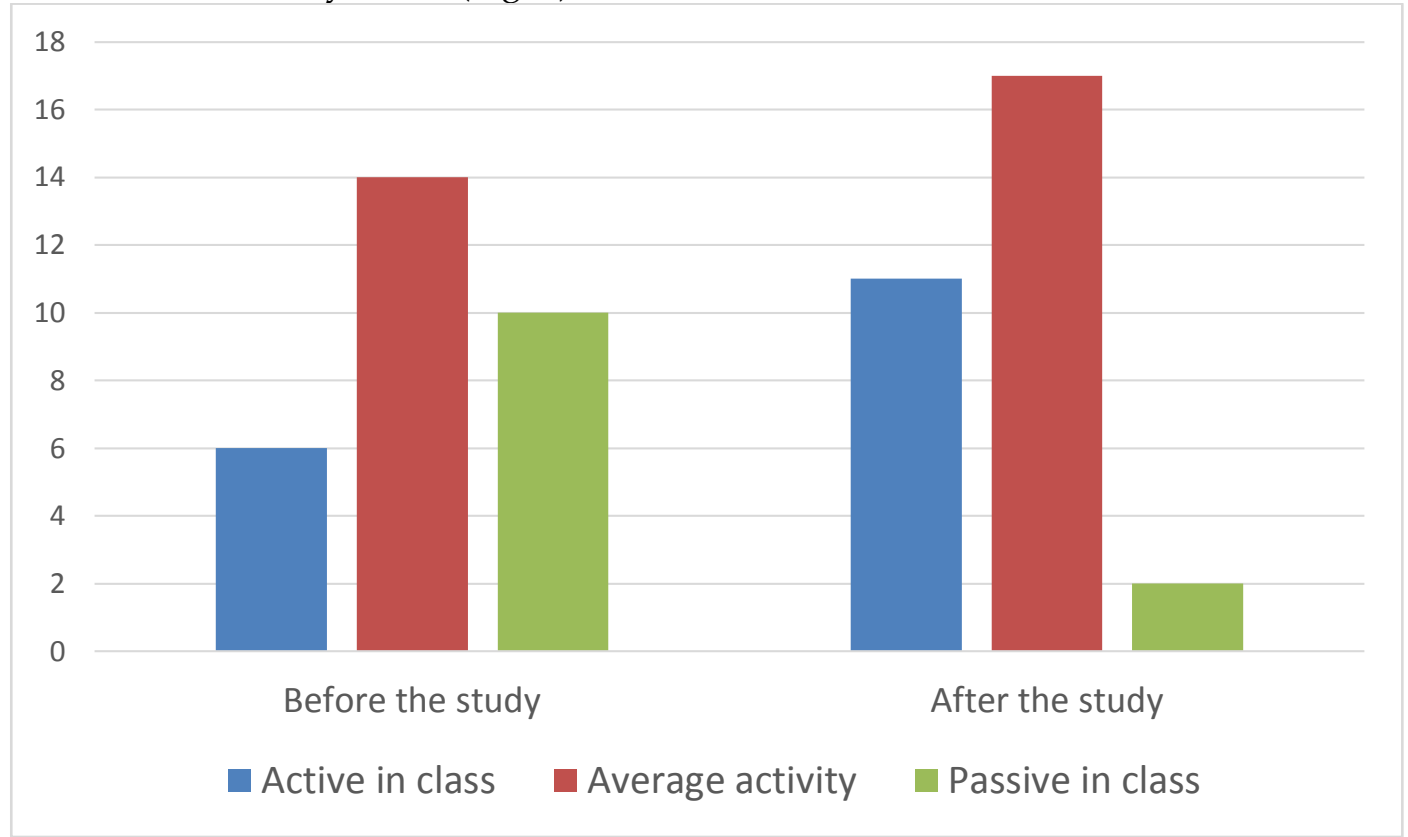

Fig. 3. Changes in the students`activity in biology lessons.

These results suggest that the main factor influencing children's learning is motivation. After all, by showing children how they can learn using modern technology, we proved that they can apply knowledge in practice. We were able to link learning to everyday life, which greatly motivated the children and led to better learning outcomes in the classroom. The assessment of the biology lesson has changed positively, which shows that children really like to work in the direction of SMART education.

\section{CONCLUSIONS}

Accordingly, summarizing the above, we can say that the essence of the regulation of behavioral deviations in the youth environment is to prevent adverse living conditions of adolescents, namely to eliminate the factors that can cause certain negative consequences. This indicates that prevention should be carried out in the form of planned actions aimed mainly at achieving the desired result and at the same time at preventing possible negative events.

It is studied that the prevention of crime in the youth environment is based on precise principles, which include: individual approach, comprehensive legality, humanism and timeliness, which are aimed at implementing a system of appropriate measures to identify and eliminate the causes and conditions that contribute to committing crimes and influence adolescents who are prone to illegal actions.

Educational work related to the regulation of behavioral deviations in the youth environment should be based on legal education. At the same time, due to the unpreparedness of specialists for the outlined work, the lack of the necessary literature the designated does not meet modern needs. Therefore, the outlined education is mainly reduced to acquainting adolescents with the key positions of the Criminal Code. At the same time, other areas of law that play no less a role in the lives of adolescents are ignored.

At the same time, the work of a social worker with adolescents prone to criminal behavior consists in establishment on relationships, joint activities, constant attention to adolescents, control, analysis of your attitude to a particular adolescent, including personal and individual approach. 
The social worker must have scientific and pedagogical knowledge about the means of influencing adolescents, their psychological peculiarities, tact, knowledge of professional ethics, organizational skills, knowledge of the forms, methods, individual and personal approach to difficult adolescents.

The current nature of the general patterns of the process of social rehabilitation of adolescents prone to criminal behavior includes the following principles: the principle of integration; the principle of systematics; the principle of an objective position in interaction with the youth environment; principle of activity; the principle of stability; the principle of positive emotional environment of adolescents.

Using detailed information about adolescents prone to criminal behavior, the social worker should apply pedagogical technologies, which consist in motivated activities that ensure the effectiveness and reliability of the results of the regulation of behavioral deviations in the youth environment.

\section{REFERENCES}

[1] Ames C. Classrooms: Goals, structure, and student motivation. Journal of Educational Psychology, (2002), 261-271.

[2] Becker K., Park K. Effects of integrative approaches among science, technology, engineering, and mathematics (STEM) subjects on students' learning. Journal of STEM Education Innovations and Research, (2008), 23-37.

[3] Blyznyuk T. Educational innovations and technological advancement in English language teaching: training teachers for NUS. Educational Horizons [Osvitni obrii]: scientific-pedagogical journal, 2 (49) (2019), 93-96. doi: 10.15330/obrii.49.2.93-96

[4] Broussard S.C., Garrison M.E.B. The relationship between classroom motivation and academic achievement in elementary school-aged children. Family and Consumer Sciences Research Journal, (2004), 106-120.

[5] Caceres-Reche M.P., Hinojo-Lucena F.J., Navas-Parejo M.R., Romero-Rodrigues J.M. The phenomenon of cyberbullying in the children and adolescents population: a scientometric analysis. Research in Social Sciences and Technology, 4 (2) (2019), 115-128. Available at: https://ressat.org/index.php/ressat/article/view/406.

[6] Christensen R., Knezek G. Alignment of Hands-on STEM Engagement Activities with Positive STEM Dispositions in Secondary School Students. Journal of Science Education and Technology, (2015), 898-909.

[7] Dedovets Z., Rodionov M. The Development of Student Core Competencies through the STEM Education Opportunities in Classroom. International Journal of Social, Behavioral, Educational, Economic, Business and Industrial Engineering, (2015), 3309-3312.

[8] Grytsai N. Innovative technologies of teaching biology: a textbook. Novyi svit, Lviv, 2019. (in Ukrainian)

[9] Komarnytska O. Features of application of mobile technologies in training. The latest information and communication technologies in the educational process: current issues: materials of the scientific-methodical conference. 2016. (in Ukrainian)

[10] Livingstone S., Smith P. Annual research review: Harms experienced by child users of online and mobile technologies: the nature, prevalence and management of sexual and aggressive risks in the digital age. J. Child Psychol. Psychiatry, 55 (6) (2014), 635-654. doi: 10.1111/jcpp.12197

[11] Naidionova L. Mediapsychology: the basics of the reflexive approach: a textbook. National Academy of Pedagogical Sciences of Ukraine, Institute of Social and Political Psychology. Imeks-LTD, Kirovograd, 2013. (in Ukrainian) 
Address: Victoria Gniezdilova, Vasyl Stefanyk Precarpathian National University, 57 Shevchenko St., IvanoFrankivsk 76018, Ukraine.

E-mail: viktoria.gniezdilova@pnu.edu.ua.

Received: 03.02.2021; revised: 16.03.2021.

Гнєздіяова Вікторія. Використання гаджетів на заняттях біології як засіб підвищення мотивації учнів. Журнал Прикарпатського університету імені Василя Стефаника, 8 (1) (2021), 174-181.

У статті висвітлено актуальну проблему мотивації учнів до навчання. Використання гаджетів в освітньому процесі, може позитивно вплинути на мотивацію школярів до навчання, залучити їх до творчої діяльності, а також зацікавити більш якісно та сумлінно виконувати завдання. Адже більшості школярів нудно в школі, їх важко залучити до активної роботи на уроці. Проблема підвищення активності учнів на уроках є досить поширеною і актуальною проблемою на сьогодні. Сьогодні важко уявити світ без сучасних технологій. Ноутбуки, мобільні телефони, планшети, комп'ютери та інші гаджети стади хорошими друзями для людини. Вони справжні колеги по роботі: допомагають виконувати численні завдання, розв'язання яких потребувало багато часу. Так само, як і для будь якого дорослого, гаджети займають визначну роль і у житті дітей. Підлітки і мобільні телефони, такі ж нерозлучні речі, як вчителі та добре заготовлені конспекти. Діти все більше обирають розваги перед монітором, замість ігор на вулиці чи прогулянок з рідними. Соціальні мережі, добре продумані комп'ютерні ігри, посіли перше місце серед хобі у молоді. Саме тому важливим завданням, яке стоїть перед учителями, - викдикати інтерес до навчання, тобто мотивувати учнів. I тут IКТ просто незамінні: вони є тим ланцюжком, який з'єднує інтереси вчителя й учнів. Тільки потрібно навчитися творчо використовувати захоплення дітей гаджетами. Проведені нами дослідження показади як змінилося ставлення учнів до уроків біології та їх мотивація до навчання після використання онлайн лабораторії на платформі Go-Lab, додатку Kahoot!, та QR-кодів.

Кдючові слова: мотивація, гаджети та електронні пристрої, навчальний процес, учні, уроки біологіiі. 